Published in final edited form as:

Mutat Res. 2017 ; 772: 3-12. doi:10.1016/j.mrrev.2016.07.002.

\title{
HUMAN PAPILLOMAVIRUS MOLECULAR BIOLOGY
}

\author{
Mallory E. Harden ${ }^{a, b}$ and Karl Munger ${ }^{b}$ \\ aProgram in Virology, Division of Medical Sciences, Harvard Medical School, Boston, MA, 02115, \\ USA \\ bepartment of Developmental, Molecular and Chemical Biology, Tufts University School of \\ Medicine, Boston, MA, 02111, USA
}

\begin{abstract}
Human papillomaviruses are small DNA viruses with a tropism for squamous epithelia. A unique aspect of human papillomavirus molecular biology involves dependence on the differentiation status of the host epithelial cell to complete the viral lifecycle. A small group of these viruses are the etiologic agents of several types of human cancers, including oral and anogenital tract carcinomas. This review focuses on the basic molecular biology of human papillomaviruses.
\end{abstract}

\section{Keywords}

Human papillomavirus; cervical cancer; oncogene; tumor suppressor; epithelial differentiation; vaccine

\subsection{Introduction}

With a prevalence of 70 million cases and an incidence of 14 million new transmissions each year, human papillomavirus (HPV) infections of the anogenital tract are the most common sexually transmitted diseases in the US [1]. High-risk (HR) HPVs are the causative agents of cervical cancer and, worldwide, it is estimated that 500,000 cases of cervical cancer occur each year, which result in over 250,000 deaths [2]. Cervical cancer is the $4^{\text {th }}$ most common cancer in women and the $7^{\text {th }}$ most common cancer overall [3]. The burden of cervical cancer is disproportionately high in low-income countries due to a scarcity in resources to implement widespread screening, vaccination and treatment programs [4]. While safe and efficacious vaccines for the prevention of HPV infection are available, they do not protect those already infected with HPV and they do not protect against all HPV types. Therefore, continued studies of the molecular biology of HPV are necessary to develop improved screening techniques and prophylactic vaccines for the prevention of HPV infection, as well as better therapeutic options, including vaccines, for the treatment of HPV infection.

Corresponding author: Mailing address: 150 Harrison Avenue, Jaharis 607, Boston, MA, 02111. Phone (617) 636-0306; Fax: (617) 636-2990, karl.munger@tufts.edu.

Publisher's Disclaimer: This is a PDF file of an unedited manuscript that has been accepted for publication. As a service to our customers we are providing this early version of the manuscript. The manuscript will undergo copyediting, typesetting, and review of the resulting proof before it is published in its final citable form. Please note that during the production process errors may be discovered which could affect the content, and all legal disclaimers that apply to the journal pertain. 


\subsection{HPV Classification}

HPVs are members of the distinct virus family, the Papillomaviridae. The Papillomaviridae family is divided into 39 genera [5, 6], based on L1 sequence identity of $60 \%$ or greater, with each genus designated by a letter of the Greek alphabet. PVs within a genus that share $60-70 \% \mathrm{~L} 1$ sequence identity are termed a species $[5,6]$. Additionally, within a species, PVs with 71-89\% L1 sequence identity are considered a type [5, 6]. As of 2016, 205 different HPV types have been identified, which have been categorized into five genera including the following: 65 Alphapapillomaviruses, 51 Betapapillomaviruses, 84 Gammapapillomaviruses, 4 Mupapillomaviruses and a single Nupapillomavirus [7]. At least 19 more additional types have been identified however, these viruses are currently pending classification. HPVs with 90-98\% L1 sequence identity are termed subtypes and those with $>98 \%$ L1 sequence identity are considered variants [5]. Arguably, HPVs in the alpha genus are of the greatest medical importance given they are associated with oral and mucosal cancers, as well as cancers of the anogenital tract. Table 1 includes a summary of main HPV genotypes and their associated diseases.

\subsection{Virion and Genome Structure and Organization}

HPVs are non-enveloped DNA viruses with a tropism for the squamous epithelium. Each virus particle consists of an icosahedral capsid of about $60 \mathrm{~nm}$ in diameter, containing a single molecule of double stranded circular DNA of approximately 8,000 base pairs [8]. Only one strand of the double stranded DNA genome is used as a template for transcription and this coding strand contains three genomic regions, including approximately ten open reading frames (ORFs) shown in Figure 1. Many viral proteins are expressed from polycistronic mRNAs $[9,10]$. The early region (E) contains up to seven ORFs encoding viral regulatory proteins and the late $(\mathrm{L})$ region encodes the two viral capsid proteins. Each ORF in the early region is designated " $E$ " followed by a numeral, indicative of the length of the ORF. The third region of the genome has been referred to as the long control region (LCR), the upstream regulatory region (URR) or the noncoding region (NCR). This genomic region contains the origin of DNA replication, as well as transcription control sequences [8].

\subsubsection{Viral Proteins}

The early HPV ORFs include E1, E2, E4, E5, E6, E7 and E8 [10, 11] (see Figure 1). E1 codes for an ATP dependent viral DNA helicase [12] that can bind to the AT-rich origin of replication and E2 proteins function in viral transcription, replication and genome partitioning. The full length E2 protein encodes a transcriptional activator. In contrast, a truncated form of $\mathrm{E} 2$ transcribed from an internal ATG and the E8^ $\mathrm{E} 2$ fusion protein repress transcription [13]. E4 is embedded within the E2 gene and is primarily expressed as an $\mathrm{E} 1^{\wedge} \mathrm{E} 4$ fusion protein during the late stages of the viral life cycle. E4 binds to cytokeratin filaments, disrupting their structure, and is thought to play a role in viral escape from cornified epithelial layers [14]. E5 is a small transmembrane protein, which has been best studied with bovine papillomavirus type 1 (BPV1). BPV1 E5 is an oncogenic small, hydrophobic, single pass transmembrane protein that forms dimers and interacts with and activates receptor tyrosine kinase receptors, including the EGF and PDGF receptors. Similar 
activities have also been ascribed to HPV E5, which encodes multi pass transmembrane proteins that share only limited sequence similarity with BPV1 E5 [15]. HPV E5 proteins have also been reported to play a role in apoptosis and in evasion of the immune response [15]. HPV E6 and E7 both drive cell cycle entry to allow genome amplification in upper epithelial layers. HR HPV E6 proteins have oncogenic activities. They bind and degrade p53, as well as cellular PDZ proteins, and they activate telomerase [16]. HR HPV E7 proteins bind and degrade the retinoblastoma tumor suppressor, $\mathrm{pRB}$, and contribute to malignant progression by inducing genomic instability $[17,18]$. The late region encodes the major (L1) and minor (L2) capsid proteins (see Figure 1). Given the L1 ORF is the most conserved among PVs, it is used for phylogenetic organization and HPV classification. Notably, L1 will spontaneously assemble into virus like particles, which is the basis for the currently available prophylactic vaccine formulations discussed in greater detail in section $1.8[19]$.

\subsection{HPVs and Cancer}

The first HPVs that were associated with cancer were beta HPV5 and 8. They were detected in warts and cancers arising in patients with a rare genetic disorder, Epidermodysplasia verruciformis (EV) [20, 21]. Most of these patients carry mutations in one of the two EVER genes, EVER1 and EVER2 (also referred to as TMC6 and TMC8, respectively), located on chromosome17q25.3 [22]. Although the molecular basis remains enigmatic, EV patients cannot efficiently clear beta HPV infections and develop warts all over their bodies. These warts can undergo malignant progression at sun-exposed areas of the body. Beta HPVs also contribute to non-melanoma skin cancers that arise as a frequent complication in long-term immunosuppressed organ transplant patients. It remains unclear whether beta HPVs contribute to non-melanoma skin cancer formation in patients that are not systemically immunosuppressed (reviewed in [23-25]). Of note, HPV sequences are not detected in every tumor cell, suggesting that these viruses may contribute to tumor induction but may not be necessary for maintenance of the transformed state. Studies with transgenic mice have shown that E6, E7 and quite uniquely E2, each have oncogenic activities.

The approximately 40 alpha HPVs that infect mucosal epithelia are classified as low-risk (LR) or HR based on their clinical association with generally benign warts or lesions that have a propensity for malignant progression. LR HPVs, for example HPV6 and HPV11, cause genital warts or oral focal epithelial hyperplasia (Heck's disease) depending on the site of infection. HR HPVs, such as HPV16 and HPV18, cause intraepithelial neoplasia, which can progress to invasive carcinoma. HR HPVs are the causative agents of approximately $5.2 \%$ of all human cancers worldwide and HR HPV associated cervical carcinoma is the $4^{\text {th }}$ most common cancer among women globally [26-28]. Almost all cervical cancers are caused by HR HPVs and two types, HPV16 and HPV18, are detected in up to $70 \%$ of all cervical cancers [29]. HR HPV infections also account for $95 \%$ of anal cancers, $70 \%$ of oropharyngeal cancers [30], $60 \%$ of vaginal cancers, $50 \%$ of vulvar cancers and $35 \%$ of penile cancers [31]. HPV16 is by far the most prevalent HPV type detected in these cancers. HPV associated cancers generally represent non-productive infections, as described in more detail in section 1.6. 


\subsection{HPV Productive Infection and Lifecycle}

A hallmark of the HPV lifecycle is its close association with the differentiation program of the infected host squamous epithelium (see Figure 2). HPVs firstly infect undifferentiated basal epithelial cells and then viral progeny are produced in differentiated daughter cells in the uppermost epithelial layers [32].

\subsubsection{Methods for Studying the Viral Lifecycle}

Historically, it has been difficult to study the PV life cycle in the laboratory. Organotypic raft cultures, in which epithelial cells are grown on a fibroblast-containing matrix at the air liquid interface where they form a stratified, skin-like structure, provided the necessary breakthrough to recapitulate the full viral life cycle and to produce infectious HPV in tissue culture $[33,34]$.

Virus like particles (VLPs) are produced by ectopic expression of L1 either alone or in combination with L2 in mammalian cells. Pseudoviruses are VPLs that contain either viral genomes or reporter plasmids and can be produced similarly. Given their relative ease of production, VLPs and pseudoviruses have been the main tools used to study HPV structure, assembly, entry and infectivity. Due to the exquisite species specificity of PVs, an animal model that closely recapitulates HPV infection and disease in humans has not been established. In 2010, a new papillomavirus (MmuPV) was identified in the common house mouse (Mus musculus), allowing studies of PVs in laboratory mice for the first time [35]. MmuPV infection of mice most closely resembles human infection by cutaneous PVs and information gleaned from studies of MmuPV infections of laboratory mice may be useful to better understand HPV associated human pathogenesis.

\subsubsection{HPV infection}

The only cells capable of undergoing cell division in the squamous epithelium are basal cells. Consequently, PVs must specifically infect these cells to allow establishment of a persistent infection. Cells in the basal epithelial layer consist of stem cells and transit amplifying cells. In order for an HPV infection to be persistently maintained, the epithelial stem cells in the basal layer must become infected [36, 37]. However, given basal epithelial cells are shielded by several layers of differentiated cells, they are not easily accessible and the virus must infect these protected cells through micro wounds that expose lower epithelial layers [8]. Additionally, cells located in the squamocolumnar transformation zone in the cervix and anus have been shown to be particularly accessible and vulnerable to HPV infection [38].

\subsubsection{Viral Attachment and Entry}

Virions bind initially to heparan sulfate proteoglycans (HSPGs), which serve as primary attachment receptors on basal cells or exposed basement membrane resulting from epithelial trauma or permeabilization [39]. Initial L1 attachment to HSPGs induces conformational changes in the virus capsid ultimately resulting in loss of affinity for the primary receptor and transfer of the virus to an as of yet poorly characterized entry receptor. Whether or not these conformational changes may be caused by cyclophilin B [40] remains a subject of 
controversy. Ultimately, the L2 amino terminus is exposed, making it susceptible to cleavage by furin-related proteases, which is necessary for infection by some HPVs [41-43]. Internalization of capsids from the cell surface is asynchronous and can take from two to four hours, with some capsids remaining on the surface much longer than others. Capsids on the surface are propelled by directed motion (surfing) from filopodia to the cell body via actin retrograde flow $[44,45]$. A delay of one to three days can occur between cell surface binding and viral genome transcription [46, 47]. However, if the infected cells are close to mitosis, nuclear entry and detection of viral gene expression can occur at much earlier time points post infection [48].

The virus is endocytosed through a potentially novel mechanism, similar to macropinocytosis, that is clathrin, caveolin and lipid raft independent [49]. Virions are then trafficked through the endosomal system where they undergo further structural changes that result in partial uncoating [50]. During viral uncoating in acidified endosomes, cyclophilin B aids in the dissociation of $\mathrm{L} 1$ from the L2/viral genome complex and L1 is targeted to lysosomes for degradation [51]. The minor capsid protein, L2, mediates delivery of the viral genome from the early endosome to the trans Golgi network through direct interactions with the retromer complex $[52,53]$. Specifically, L2 associates with sorting nexin 17 to allow escape of the L2/viral genome complex from late endosomal compartments [54]. This interaction is conserved across multiple HPV types and is essential for viral infection [55]. L2 also directly interacts with sorting nexin 27, another member of the host retromer complex, to aid in viral trafficking [56]. Movement of the virus through the cytoplasm to the nucleus likely occurs along microtubules through the association of L2-associated vesicles with the motor protein dynein light chains $[57,58]$. Entry of the viral genome into the nucleus requires mitosis [59] and this process is mediated by L2. Following nuclear entry, L2 and the viral genome colocalize at ND10 domains, which is a critical step in the establishment of infection and allows transcription of the viral genome [60].

\subsubsection{Genome Replication and Gene Expression}

After infection, initial genome amplification occurs prior to maintenance of the viral genome in the nuclei of infected basal epithelial cells. Viral DNA is maintained in basal epithelial cells as a stable multicopy plasmid or episome. E1 and E2 are among the first viral proteins to be expressed and, while initial amplification is thought to require E1 and E2, E1 may not be necessary once viral copy numbers have reached a threshold of 50-100 copies [61]. Based on studies of cell lines, episomal copy number is thought to be approximately 200 copies per cell [62]. However, using laser capture methods, 50-100 copies per cell have been detected in the basal layer of productive warts [61]. Viral genomes replicate once per cell cycle, on average, during S phase, ensuring persistent infection of basal cells. In this "latent" phase of the viral lifecycle, HPV genomes are thought to persist in basal epithelial cells for years to decades. However, at some point, a switch from stable replication (genome maintenance) to vegetative viral DNA replication must occur to allow the production of genomes for packaging into virions. Little is known about the mechanism regulating this switch. 
Vegetative viral DNA replication occurs in differentiating cells of the squamous epithelium. Two HPV proteins, E1 and E2, are actively involved in viral genome replication. E1 is the only virally encoded enzyme and functions as an ATP dependent helicase [12]. E1 binds AT rich sequences at the origin of replication with weak affinity and is required for initiation and elongation of viral DNA synthesis. E2 stabilizes E1 binding to the origin of replication, by interacting with ACCN6GGT sequences adjacent to the origin, resulting in high affinity binding of the E1/E2 complex to the origin of replication [13]. HPVs do not encode any other replication enzymes and must hijack the host DNA synthesis machinery to accomplish replication of the viral genome. E1 and E2 recruit cellular DNA polymerases and other essential accessory enzymes to enable viral genome replication. Normally, differentiating cells would not be capable of supporting DNA synthesis given they have withdrawn from the cell cycle upon exiting the basal layer of the epithelium. However, HPVs are able to activate cellular DNA replication machinery to allow vegetative viral DNA synthesis through the actions of E6 and E7.

E6 and E7 contribute to the viral lifecycle by modifying the cellular environment to allow viral genome amplification in growth arrested, terminally differentiated cells, which would normally be incompetent for DNA replication. In particular, HR E6 and E7 drive cell proliferation in the basal and parabasal layers causing an increase in the size of the initial infected area. Many papillomavirus E7 proteins target the retinoblastoma tumor suppressor pRB and the related "pocket proteins" p107 and p130 [18, 63-66]. HR HPV E7 proteins target the pocket proteins for degradation through the ubiquitin/proteasome system. By binding and/or triggering degradation of pocket proteins, E7 causes release of E2F family members from pocket protein bound transcriptional repressor complexes. This results in constitutive activation of E2F modulated gene expression programs that control DNA synthesis and cell proliferation [67]. Additionally, some HPV E7 proteins avoid triggering G1 arrest during epithelial cell differentiation by inactivating the CDK2 inhibitors, CDKN1A and CDKN1B (reviewed in [68]).

High-risk HPV E6 proteins inactivate the p53 tumor suppressor by targeting it for proteasomal degradation through the associated E3 ubiquitin ligase, UBE3A (E6AP). This action blocks the anti proliferative and pro apoptotic activities of p53 in response to DNA damage and cellular stress caused by aberrant S-phase entry [69]. HR HPV E6 expression also upregulates telomerase activity, allowing the maintenance of telomere integrity despite repeated cell divisions [70-72]. Additionally, HR HPV E6 proteins target cellular PDZ domain containing proteins that regulate cell contact and signaling pathways [73, 74]. LR HPV E6 proteins, while able to interact with UBE3A, do not directly bind p53, but may target $\mathrm{p} 53$ transcriptional activity indirectly by binding to $\mathrm{p} 300$ and/or TIP60 [75] [76]. Moreover, LR HPV E6 proteins do not activate telomerase activity and lack the C-terminal PDZ binding domain. Beta HPV E6 proteins do not appear to target any of these pathways but have been reported to inhibit NOTCH and TGF $\beta$ signaling by associating with MAML and SMAD proteins, respectively [77-80]. The biochemical and biological activities of E6 and $\mathrm{E} 7$ are reviewed in more detail in another article in this issue.

It is important to note that infection by HPVs induces a DNA damage response (DDR) and HPVs hijack both the ATR and ATM DDR signaling pathways for their differentiation- 
dependent life cycles (reviewed in [81]). The ATM pathway is particularly important for differentiation-dependent genome amplification. HPV E1 and E7 activate the ATM DDR and E2 can also modulate this pathway through binding to E1 [82, 83]. Additionally, the ATR pathway appears to play a role in HPV replication in undifferentiated cells by affecting episomal maintenance $[84,85]$.

\subsubsection{Assembly, Maturation and Viral Release}

Completion of the viral lifecycle involves cell cycle exit and expression of L1 and L2 to allow genome packaging. Virion assembly occurs in the nuclei of terminally differentiated keratinocytes, in which viral genome replication and expression of viral proteins has occurred [8]. Nuclear entry of L1 and L2 is mediated by cellular karyopherins [86, 87], which transport molecules between the nucleus and the cytoplasm. L1 can assemble into VLPs and L2 may increase the efficiency of this reaction [88, 89]. Packaging of the viral genome is not thought to be sequence specific [90] and may involve a size determination mechanism [8]. Maturation of viral particles occurs in the upper layers of terminally differentiated squamous epithelia, where particles are exposed to an oxidizing environment. This maturation process involves the accumulation of disulfide bonds between L1 proteins, resulting in condensation of the capsid, thereby increasing its stability and resistance to proteolytic digestion [91]. HPVs are non lytic and viral shedding occurs due to normal loss of nuclear and cytoplasmic integrity during terminal differentiation of the infected keratinocyte [8]. E4 may also contribute to virion release by binding to cytokeratin filaments and disrupting their structure [14].

\subsection{Non-Productive HPV Infection and Transformation}

HR HPV associated cancers frequently represent non-productive infections, in which viral proteins are expressed but no infectious virus is produced. Deregulation of viral gene expression can be caused by viral genome integration in high-grade premalignant lesions, often resulting in expression of just two viral proteins, E6 and E7. Such integration events frequently cause disruption or deletion of the E2 ORF, which encodes a transcriptional repressor of E6/E7 expression [92, 93]. Hence, E6/E7 mRNA expression may be higher from integrated HPV subgenomes. Additionally, E6/E7 mRNAs produced from integrated genomes have been reported to be more stable than mRNAs expressed from episomal genomes [94]. A genome wide analysis of HPV genomes in cervical lesions and cancers showed that HPV integration sites frequently directly flank chromosomal aberrations that include focal amplifications, rearrangements, deletions and/or translocations [95]. Based on a "looping" model, these host genomic alterations are triggered when HPV integrant mediated DNA replication and recombination form viral host DNA concatemers. This also results in amplification of E6 and E7 containing viral genome fragments [95]. It is interesting to note, however, that some cervical cancers retain viral genomes in episomal form [96-98]. In these cases, viral gene expression is likely deregulated by aberrant epigenetic modifications of the viral genome (reviewed in [99]).

Therefore, the expression of E6 and E7 is deregulated in cervical carcinomas on multiple levels and the expression of cellular genes flanking sites of viral genome integration may 
also be compromised, at least in those cases where viral genome integration has occurred [100]. Furthermore, in cervical disease, it is thought that expression of E6 and E7 underlies the distinctive neoplastic phenotypes (reviewed in [62]). E6 and E7 expression is thought to increase during progression from cervical intraepithelial neoplasia 1 (CIN1) to CIN3 and, given the ability of HR, but not LR HPV E6 and E7 proteins, to trigger genomic instability, E6 and E7 expression importantly contribute to malignant progression [101, 102]. A recent study has shown that cervical carcinomas contain recurrent mutations in cellular genes including EP300, FBXW7, PIK3CA, HLA-B, TP53, MAPK1, PTEN, ERBB2, NFE2L2 and STK11 [100].

\subsection{Prevention of HPV- Associated Diseases and Cancer}

Routine screening is critical for the early detection of HPV and prevention of associated diseases and cancer. The Papanicolaou smear, or the Pap test, has been the method of choice for cervical cancer screening for over 60 years [103]. Since its widespread implementation, cervical cancer deaths have decreased dramatically. However, the Pap test has a relatively high rate of false positives, as well as false negatives. In 2014, the U.S. Food and Drug Administration (FDA) approved a PCR based HPV test (the cobas HPV test) that detects HR types and genotypes HPV16 and 18, as well as 12 other HR HPVs, for primary screening in cervical cancer [104]. Similar to many other countries, screening guidelines were updated in the US to recommend HPV primary screening as an alternative to cytology based screening strategies [105]. Routine screening options now include cytology alone, cytology in conjunction with HPV testing with or without genotyping or HPV primary screening with genotyping [106]. The incorporation of HPV genotyping into cervical cancer screening is thought to decrease the incidence of cervical cancer by improving the detection of CIN [107]. While condoms have been shown to reduce the risk of HPV infection [108, 109], as well as a lubricant, carrageenan [47] and a carrageenan-based microbicide, Carraguard [110], the best and most efficacious method of prevention is vaccination.

\subsection{HPV Vaccination}

Vaccination is the only effective measure to prevent HPV infection, and development of a prophylactic HPV vaccine was widely hailed as a historic achievement. Vaccination against HPVs has been in effect since 2006 and the three currently available prophylactic vaccines are composed of recombinant HPV L1 capsid proteins that self assemble into VLPs and induce the production of high level, neutralizing, type specific antibodies by eliciting a strong B cell mediated immune response [8]. All three vaccines are administered as three injections over a time period of six months and the immune response to vaccination is superior to the response to natural infection, thus providing long-term immunity [111, 112].

Gardasi ${ }^{\circledR}$ was the first approved HPV vaccine and includes VLPs of the most prevalent LR (HPV6, HPV11) and HR (HPV16, HPV18) HPVs. Another HPV vaccine, Cervarix ${ }^{\circledR}$, was developed by GlaxoSmithKline (GSK) and is a bivalent vaccine targeting HPV16 and HPV18. In 2014, the FDA approved the newest HPV vaccine, Gardasil $9^{\circledR}$, which protects against 9 HPVs, including HPV16, 18, 6, 11, 31, 33, 45, 52 and 58. The five additional HPV genotypes Gardasil $9^{\circledR}$ protects against account for an additional $15-20 \%$ of cervical cancer 
cases [113]. As a result, vaccination has the potential to prevent $~ 90 \%$ of cervical cancer cases [114]. The Advisory Committee on Immunization Practices (ACIP) currently recommends one of the three HPV vaccines for routine vaccination at 11-12 years of age [115]. The ACIP also recommends vaccination for females age 13-26, males age 13-21 and men who have sex with men through age 26 , as well as immunocompromised individuals not previously vaccinated [115].

Cervarix ${ }^{\circledR}$ and Gardasil ${ }^{\circledR}$ both have excellent safety profiles and have been shown to be highly efficacious against infections with their respective HPV types [116-120]. Both vaccines also show some limited cross protection against HPV types not targeted by the vaccines $[118,119,121,122]$. In vaccination programs with high coverage rates, these vaccines have been shown to induce herd immunity [123-125].

Although the effects of the vaccines on the incidence of cervical and other HPV related cancers are not likely to be realized for several decades [126], a decrease in the incidence of HPV infections, precancerous lesions and genital warts has already been demonstrated in multiple studies (reviewed in [127]). However, given these vaccines are prophylactic, they are designed to prevent HPV infection from occurring and are no longer effective once HPV infection has already been established [128]. As a result, several therapeutic HPV vaccines, designed to treat patients with established HPV infection or even those with CIN, are currently in development (reviewed in [129]). The discovery of immunological checkpoint inhibitors has also greatly re-energized these efforts. However, no therapeutic HPV vaccines are currently available on the market.

\subsection{Concluding Remarks}

Historically, the field of PV research has experienced many exciting breakthroughs since the discovery of the first animal PV by Richard Shope in the 1930s [130]. Widespread implementation of the Pap smear in the 1960s greatly reduced the incidence and mortality of cervical cancer [103]. The incidence of cervical cancer declined by half from 1975 to 2012 in the US and, similarly, the death rate from cervical cancer in the US in 2012 was less than half of what it was in 1975 [131]. These dramatic declines are due to early detection of cervical cancer with the Pap test and provide the most compelling validation of the concept that early detection can dramatically decrease cancer incidence and mortality. While a similar cytological test is used for early detection of anal cancer in high-risk populations [132], it is important to note that there are currently no similar procedures for the early detection of HPV-associated oropharyngeal cancers.

Before the introduction of HPV vaccines in 2006, it was estimated that one woman died every 10 minutes as a result of cervical cancer globally [133]. A decline in vaccine type HPV prevalence of $56 \%$ was observed over a four year period in the US following implementation of Cervarix ${ }^{\circledR}$ and Gardasil ${ }^{\circledR}$ [134]. These numbers are impressive given the vaccination rate was relatively low at the time of the study ( 32\%) [134]. While the complete benefit of vaccine protection again HPV-associated cancers and diseases will not be observed for several decades, the results thus far are extremely promising. With the advent of Gardasil $9^{\circledR}$ in 2014, and the promise of other prophylactic and therapeutic 
vaccines currently in development, it is likely that the burden of HPV-associated diseases and cancer will decrease even more dramatically.

\section{Acknowledgments}

Research in the authors group is supported by PHS grant R01 CA066980 (KM). MEH is supported by F31 CA180516.

\section{References}

1. CDC. Epidemiology and Prevention of Vaccine-Preventable Diseases. 13. Washington, D.C.: Public Health Foundation; 2015.

2. Schiffman M, Castle PE, Jeronimo J, Rodriguez AC, Wacholder S. Human papillomavirus and cervical cancer. Lancet. 2007; 370:890-907. [PubMed: 17826171]

3. Bray F, Ren JS, Masuyer E, Ferlay J. Global estimates of cancer prevalence for 27 sites in the adult population in 2008. Int J Cancer. 2013; 132:1133-1145. [PubMed: 22752881]

4. Forman D, de Martel C, Lacey CJ, Soerjomataram I, Lortet-Tieulent J, Bruni L, Vignat J, Ferlay J, Bray F, Plummer M, Franceschi S. Global burden of human papillomavirus and related diseases. Vaccine. 2012; (30 Suppl 5):F12-F23. [PubMed: 23199955]

5. Bernard HU, Burk RD, Chen Z, van Doorslaer K, zur Hausen H, de Villiers EM. Classification of papillomaviruses (PVs) based on $189 \mathrm{PV}$ types and proposal of taxonomic amendments. Virology. 2010; 401:70-79. [PubMed: 20206957]

6. de Villiers EM, Fauquet C, Broker TR, Bernard HU, zur Hausen H. Classification of papillomaviruses. Virology. 2004; 324:17-27. [PubMed: 15183049]

7. Van Doorslaer K, Tan Q, Xirasagar S, Bandaru S, Gopalan V, Mohamoud Y, Huyen Y, McBride AA. The Papillomavirus Episteme: a central resource for papillomavirus sequence data and analysis. Nucleic Acids Res. 2013; 41:D571-D578. [PubMed: 23093593]

8. Knipe, DM., Howley, PM. Fields virology. 6th. Philadelphia, PA: Wolters Kluwer/Lippincott Williams \& Wilkins Health; 2013.

9. Favre M, Orth G, Croissant O, Yaniv M. Human papillomavirus DNA: physical map. Proc Natl Acad Sci U S A. 1975; 72:4810-4814. [PubMed: 174077]

10. Zheng ZM, Baker CC. Papillomavirus genome structure, expression, and post-transcriptional regulation. Front Biosci. 2006; 11:2286-2302. [PubMed: 16720315]

11. Doorbar J, Campbell D, Grand RJ, Gallimore PH. Identification of the human papilloma virus-1a E4 gene products. EMBO J. 1986; 5:355-362. [PubMed: 3011404]

12. Bergvall M, Melendy T, Archambault J. The E1 proteins. Virology. 2013; 445:35-56. [PubMed: 24029589]

13. McBride AA. The papillomavirus E2 proteins. Virology. 2013; 445:57-79. [PubMed: 23849793]

14. Doorbar J, The E4 protein; structure. function and patterns of expression. Virology. 2013; 445:8098. [PubMed: 24016539]

15. DiMaio D, Petti LM. The E5 proteins. Virology. 2013; 445:99-114. [PubMed: 23731971]

16. Vande Pol SB, Klingelhutz AJ. Papillomavirus E6 oncoproteins. Virology. 2013; 445:115-137. [PubMed: 23711382]

17. Roman A, Munger K. The papillomavirus E7 proteins. Virology. 2013; 445:138-168. [PubMed: 23731972]

18. Dyson N, Howley PM, Munger K, Harlow E. The human papilloma virus-16 E7 oncoprotein is able to bind to the retinoblastoma gene product. Science. 1989; 243:934-937. [PubMed: 2537532]

19. Buck CB, Day PM, Trus BL. The papillomavirus major capsid protein L1. Virology. 2013; 445:169-174. [PubMed: 23800545]

20. Pass F, Reissig M, Shah KV, Eisinger M, Orth G. Identification of an immunologically distinct papillomavirus from lesions of epidermodysplasia verruciformis. J Natl Cancer Inst. 1977; 59:1107-1112. [PubMed: 71354] 
21. Orth G, Jablonska S, Favre M, Croissant O, Jarzabek-Chorzelska M, Rzesa G. Characterization of two types of human papillomaviruses in lesions of epidermodysplasia verruciformis. Proc Natl Acad Sci U S A. 1978; 75:1537-1541. [PubMed: 206906]

22. Ramoz N, Rueda LA, Bouadjar B, Montoya LS, Orth G, Favre M. Mutations in two adjacent novel genes are associated with epidermodysplasia verruciformis. Nat Genet. 2002; 32:579-581. [PubMed: 12426567]

23. Pfister H. Chapter 8: Human papillomavirus and skin cancer. J Natl Cancer Inst Monogr. 2003:5256. [PubMed: 12807946]

24. Meyers JM, Munger K. The viral etiology of skin cancer. J Invest Dermatol. 2014; 134:E29-E32. [PubMed: 25302471]

25. Orth G. Host defenses against human papillomaviruses: lessons from epidermodysplasia verruciformis. Curr Top Microbiol Immunol. 2008; 321:59-83. [PubMed: 18727487]

26. de Martel C, Ferlay J, Franceschi S, Vignat J, Bray F, Forman D, Plummer M. Global burden of cancers attributable to infections in 2008: a review and synthetic analysis. Lancet Oncol. 2012; 13:607-615. [PubMed: 22575588]

27. Chaturvedi AK. Beyond cervical cancer: burden of other HPV-related cancers among men and women. J Adolesc Health. 2010; 46:S20-S26. [PubMed: 20307840]

28. Tota JE, Chevarie-Davis M, Richardson LA, Devries M, Franco EL. Epidemiology and burden of HPV infection and related diseases: implications for prevention strategies. Prev Med. 2011; (53 Suppl 1):S12-S21. [PubMed: 21962466]

29. Winer RL, Hughes JP, Feng Q, O’Reilly S, Kiviat NB, Holmes KK, Koutsky LA. Condom use and the risk of genital human papillomavirus infection in young women. N Engl J Med. 2006; 354:2645-2654. [PubMed: 16790697]

30. Chaturvedi AK, Engels EA, Pfeiffer RM, Hernandez BY, Xiao W, Kim E, Jiang B, Goodman MT, Sibug-Saber M, Cozen W, Liu L, Lynch CF, Wentzensen N, Jordan RC, Altekruse S, Anderson WF, Rosenberg PS, Gillison ML. Human papillomavirus and rising oropharyngeal cancer incidence in the United States. J Clin Oncol. 2011; 29:4294-4301. [PubMed: 21969503]

31. Gillison ML, Chaturvedi AK, Lowy DR. HPV prophylactic vaccines and the potential prevention of noncervical cancers in both men and women. Cancer. 2008; 113:3036-3046. [PubMed: 18980286]

32. Hong S, Laimins LA. Regulation of the life cycle of HPVs by differentiation and the DNA damage response. Future Microbiol. 2013; 8:1547-1557. [PubMed: 24266355]

33. Meyers C, Frattini MG, Hudson JB, Laimins LA. Biosynthesis of human papillomavirus from a continuous cell line upon epithelial differentiation. Science. 1992; 257:971-973. [PubMed: 1323879]

34. Dollard SC, Wilson JL, Demeter LM, Bonnez W, Reichman RC, Broker TR, Chow LT. Production of human papillomavirus and modulation of the infectious program in epithelial raft cultures. OFF. Genes Dev. 1992; 6:1131-1142. [PubMed: 1321068]

35. Ingle A, Ghim S, Joh J, Chepkoech I, Bennett Jenson A, Sundberg JP. Novel laboratory mouse papillomavirus (MusPV) infection. Vet Pathol. 2011; 48:500-505. [PubMed: 20685915]

36. Kaur P, Li A. Adhesive properties of human basal epidermal cells: an analysis of keratinocyte stem cells, transit amplifying cells, and postmitotic differentiating cells. J Invest Dermatol. 2000; 114:413-420. [PubMed: 10692098]

37. Egawa K. Do human papillomaviruses target epidermal stem cells? Dermatology. 2003; 207:251254. [PubMed: 14571065]

38. Herfs M, Yamamoto Y, Laury A, Wang X, Nucci MR, McLaughlin-Drubin ME, Munger K, Feldman S, McKeon FD, Xian W, Crum CP. A discrete population of squamocolumnar junction cells implicated in the pathogenesis of cervical cancer. Proc Natl Acad Sci U S A. 2012; 109:10516-10521. [PubMed: 22689991]

39. Schafer G, Blumenthal MJ, Katz AA. Interaction of human tumor viruses with host cell surface receptors and cell entry. Viruses. 2015; 7:2592-2617. [PubMed: 26008702]

40. Bienkowska-Haba M, Patel HD, Sapp M. Target cell cyclophilins facilitate human papillomavirus type 16 infection. PLoS Pathog. 2009; 5:e1000524. [PubMed: 19629175] 
41. Richards RM, Lowy DR, Schiller JT, Day PM. Cleavage of the papillomavirus minor capsid protein, L2 at a furin consensus site is necessary for infection. Proc Natl Acad Sci U S A. 2006; 103:1522-1527. [PubMed: 16432208]

42. Day PM, Schiller JT. The role of furin in papillomavirus infection. Future Microbiol. 2009; 4:1255-1262. [PubMed: 19995186]

43. Cruz L, Biryukov J, Conway MJ, Meyers C. Cleavage of the HPV16 Minor Capsid Protein L2 during Virion Morphogenesis Ablates the Requirement for Cellular Furin during De Novo Infection. Viruses. 2015; 7:5813-5830. [PubMed: 26569287]

44. Schelhaas M, Ewers H, Rajamaki ML, Day PM, Schiller JT, Helenius A. Human papillomavirus type 16 entry: retrograde cell surface transport along actin-rich protrusions. PLoS Pathog. 2008; 4:e1000148. [PubMed: 18773072]

45. Smith JL, Lidke DS, Ozbun MA. Virus activated filopodia promote human papillomavirus type 31 uptake from the extracellular matrix. Virology. 2008; 381:16-21. [PubMed: 18834609]

46. Day PM, Lowy DR, Schiller JT. Papillomaviruses infect cells via a clathrin-dependent pathway. Virology. 2003; 307:1-11. [PubMed: 12667809]

47. Roberts JN, Buck CB, Thompson CD, Kines R, Bernardo M, Choyke PL, Lowy DR, Schiller JT. Genital transmission of HPV in a mouse model is potentiated by nonoxynol- 9 and inhibited by carrageenan. Nat Med. 2007; 13:857-861. [PubMed: 17603495]

48. Broniarczyk J, Massimi P, Bergant M, Banks L. Human Papillomavirus Infectious Entry and Trafficking Is a Rapid Process. J Virol. 2015; 89:8727-8732. [PubMed: 26063434]

49. Schelhaas M, Shah B, Holzer M, Blattmann P, Kuhling L, Day PM, Schiller JT, Helenius A, Entry of human papillomavirus type 16 by actin-dependent. clathrin- and lipid raft-independent endocytosis. PLoS Pathog. 2012; 8:e1002657. [PubMed: 22536154]

50. Day PM, Schelhaas M. Concepts of papillomavirus entry into host cells. Curr Opin Virol. 2014; 4:24-31. [PubMed: 24525291]

51. Bienkowska-Haba M, Williams C, Kim SM, Garcea RL, Sapp M. Cyclophilins facilitate dissociation of the human papillomavirus type 16 capsid protein L1 from the L2/DNA complex following virus entry. J Virol. 2012; 86:9875-9887. [PubMed: 22761365]

52. Popa A, Zhang W, Harrison MS, Goodner K, Kazakov T, Goodwin EC, Lipovsky A, Burd CG, DiMaio D. Direct binding of retromer to human papillomavirus type 16 minor capsid protein L2 mediates endosome exit during viral infection. PLoS Pathog. 2015; 11:e1004699. [PubMed: 25693203]

53. Bonifacino JS, Hurley JH. Retromer. Curr Opin Cell Biol. 2008; 20:427-436. [PubMed: 18472259]

54. Bergant Marusic M, Ozbun MA, Campos SK, Myers MP, Banks L. Human papillomavirus L2 facilitates viral escape from late endosomes via sorting nexin 17. Traffic. 2012; 13:455-467. [PubMed: 22151726]

55. Bergant M, Banks L. SNX17 facilitates infection with diverse papillomavirus types. J Virol. 2013; 87:1270-1273. [PubMed: 23115288]

56. Pim D, Broniarczyk J, Bergant M, Playford MP, Banks L. A Novel PDZ Domain Interaction Mediates the Binding between Human Papillomavirus 16 L2 and Sorting Nexin 27 and Modulates Virion Trafficking. J Virol. 2015; 89:10145-10155. [PubMed: 26202251]

57. Florin L, Becker KA, Lambert C, Nowak T, Sapp C, Strand D, Streeck RE, Sapp M. Identification of a dynein interacting domain in the papillomavirus minor capsid protein 12. J Virol. 2006; 80:6691-6696. [PubMed: 16775357]

58. Schneider MA, Spoden GA, Florin L, Lambert C. Identification of the dynein light chains required for human papillomavirus infection. Cell Microbiol. 2011; 13:32-46. [PubMed: 21166973]

59. Pyeon D, Pearce SM, Lank SM, Ahlquist P, Lambert PF. Establishment of human papillomavirus infection requires cell cycle progression. PLoS Pathog. 2009; 5:e1000318. [PubMed: 19247434]

60. Day PM, Baker CC, Lowy DR, Schiller JT. Establishment of papillomavirus infection is enhanced by promyelocytic leukemia protein (PML) expression. Proc Natl Acad Sci U S A. 2004; 101:14252-14257. [PubMed: 15383670] 
61. Maglennon GA, McIntosh P, Doorbar J. Persistence of viral DNA in the epithelial basal layer suggests a model for papillomavirus latency following immune regression. Virology. 2011; 414:153-163. [PubMed: 21492895]

62. Doorbar J, Egawa N, Griffin H, Kranjec C, Murakami I. Human papillomavirus molecular biology and disease association. Rev Med Virol. 2015; (25 Suppl 1):2-23. [PubMed: 25752814]

63. Klingelhutz AJ, Roman A. Cellular transformation by human papillomaviruses: lessons learned by comparing high- and low-risk viruses. Virology. 2012; 424:77-98. [PubMed: 22284986]

64. Barrow-Laing L, Chen W, Roman A. Low- and high-risk human papillomavirus E7 proteins regulate p130 differently. Virology. 2010; 400:233-239. [PubMed: 20189212]

65. Roman A. The human papillomavirus E7 protein shines a spotlight on the pRB family member, p130. Cell Cycle. 2006; 5:567-568. [PubMed: 16582614]

66. Felsani A, Mileo AM, Paggi MG. Retinoblastoma family proteins as key targets of the small DNA virus oncoproteins. Oncogene. 2006; 25:5277-5285. [PubMed: 16936748]

67. Munger K, Howley PM. Human papillomavirus immortalization and transformation functions. Virus Res. 2002; 89:213-228. [PubMed: 12445661]

68. Moody CA, Laimins LA. Human papillomavirus oncoproteins: pathways to transformation. Nat Rev Cancer. 2010; 10:550-560. [PubMed: 20592731]

69. Scheffner M, Huibregtse JM, Vierstra RD, Howley PM. The HPV-16 E6 and E6-AP complex functions as a ubiquitin-protein ligase in the ubiquitination of p53. Cell. 1993; 75:495-505. [PubMed: 8221889]

70. Klingelhutz AJ, Foster SA, McDougall JK. Telomerase activation by the E6 gene product of human papillomavirus type 16. Nature. 1996; 380:79-82. [PubMed: 8598912]

71. Gewin L, Galloway DA. E box-dependent activation of telomerase by human papillomavirus type 16 E6 does not require induction of c-myc. J Virol. 2001; 75:7198-7201. [PubMed: 11435602]

72. Galloway DA, Gewin LC, Myers H, Luo W, Grandori C, Katzenellenbogen RA, McDougall JK. Regulation of telomerase by human papillomaviruses. Cold Spring Harb Symp Quant Biol. 2005; 70:209-215. [PubMed: 16869756]

73. Kiyono T, Hiraiwa A, Fujita M, Hayashi Y, Akiyama T, Ishibashi M. Binding of high-risk human papillomavirus E6 oncoproteins to the human homologue of the Drosophila discs large tumor suppressor protein. Proc Natl Acad Sci U S A. 1997; 94:11612-11616. [PubMed: 9326658]

74. Lee SS, Weiss RS, Javier RT. Binding of human virus oncoproteins to hDlg/SAP97, a mammalian homolog of the Drosophila discs large tumor suppressor protein. Proc Natl Acad Sci U S A. 1997; 94:6670-6675. [PubMed: 9192623]

75. Thomas MC, Chiang CM. E6 oncoprotein represses p53-dependent gene activation via inhibition of protein acetylation independently of inducing p53 degradation. Mol Cell. 2005; 17:251-264. [PubMed: 15664194]

76. Jha S, Vande Pol S, Banerjee NS, Dutta AB, Chow LT, Dutta A. Destabilization of TIP60 by human papillomavirus E6 results in attenuation of TIP60-dependent transcriptional regulation and apoptotic pathway. Mol Cell. 2010; 38:700-711. [PubMed: 20542002]

77. Brimer N, Lyons C, Wallberg AE, Vande Pol SB. Cutaneous papillomavirus E6 oncoproteins associate with MAML1 to repress transactivation and NOTCH signaling. Oncogene. 2012; 31:4639-4646. [PubMed: 22249263]

78. Tan MJ, White EA, Sowa ME, Harper JW, Aster JC, Howley PM. Cutaneous beta-human papillomavirus E6 proteins bind Mastermind-like coactivators and repress Notch signaling. Proc Natl Acad Sci U S A. 2012; 109:E1473-E1480. [PubMed: 22547818]

79. Rozenblatt-Rosen O, Deo RC, Padi M, Adelmant G, Calderwood MA, Rolland T, Grace M, Dricot A, Askenazi M, Tavares M, Pevzner SJ, Abderazzaq F, Byrdsong D, Carvunis AR, Chen AA, Cheng J, Correll M, Duarte M, Fan C, Feltkamp MC, Ficarro SB, Franchi R, Garg BK, Gulbahce N, Hao T, Holthaus AM, James R, Korkhin A, Litovchick L, Mar JC, Pak TR, Rabello S, Rubio R, Shen Y, Singh S, Spangle JM, Tasan M, Wanamaker S, Webber JT, Roecklein-Canfield J, Johannsen E, Barabasi AL, Beroukhim R, Kieff E, Cusick ME, Hill DE, Munger K, Marto JA, Quackenbush J, Roth FP, DeCaprio JA, Vidal M. Interpreting cancer genomes using systematic host network perturbations by tumour virus proteins. Nature. 2012; 487:491-495. [PubMed: 22810586] 
80. Mendoza JA, Jacob Y, Cassonnet P, Favre M. Human papillomavirus type 5 E6 oncoprotein represses the transforming growth factor beta signaling pathway by binding to SMAD3. J Virol. 2006; 80:12420-12424. [PubMed: 17020941]

81. Hong S, Laimins LA. Regulation of the life cycle of HPVs by differentiation and the DNA damage response. Future Microbiol. 2013; 8:1547-1557. [PubMed: 24266355]

82. Sakakibara N, Mitra R, McBride AA. The papillomavirus E1 helicase activates a cellular DNA damage response in viral replication foci. Journal of virology. 2011; 85:8981-8995. [PubMed: 21734054]

83. Fradet-Turcotte A, Bergeron-Labrecque F, Moody CA, Lehoux M, Laimins LA, Archambault J. Nuclear accumulation of the papillomavirus E1 helicase blocks S-phase progression and triggers an ATM-dependent DNA damage response. Journal of virology. 2011; 85:8996-9012. [PubMed: 21734051]

84. Reinson T, Toots M, Kadaja M, Pipitch R, Allik M, Ustav E, Ustav M. Engagement of the ATRdependent DNA damage response at the human papillomavirus 18 replication centers during the initial amplification. Journal of virology. 2013; 87:951-964. [PubMed: 23135710]

85. Edwards TG, Helmus MJ, Koeller K, Bashkin JK, Fisher C. Human papillomavirus episome stability is reduced by aphidicolin and controlled by DNA damage response pathways. Journal of virology. 2013; 87:3979-3989. [PubMed: 23365423]

86. Merle E, Rose RC, LeRoux L, Moroianu J. Nuclear import of HPV11 L1 capsid protein is mediated by karyopherin alpha2beta1 heterodimers. J Cell Biochem. 1999; 74:628-637. [PubMed: 10440932]

87. Darshan MS, Lucchi J, Harding E, Moroianu J. The 12 minor capsid protein of human papillomavirus type 16 interacts with a network of nuclear import receptors. J Virol. 2004; 78:12179-12188. [PubMed: 15507604]

88. Kirnbauer R, Taub J, Greenstone H, Roden R, Durst M, Gissmann L, Lowy DR, Schiller JT. Efficient self-assembly of human papillomavirus type 16 L1 and L1-L2 into virus-like particles. J Virol. 1993; 67:6929-6936. [PubMed: 8230414]

89. Zhou J, Sun XY, Stenzel DJ, Frazer IH. Expression of vaccinia recombinant HPV 16 L1 and L2 ORF proteins in epithelial cells is sufficient for assembly of HPV virion-like particles. Virology. 1991; 185:251-257. [PubMed: 1656586]

90. Buck CB, Pastrana DV, Lowy DR, Schiller JT. Efficient intracellular assembly of papillomaviral vectors. J Virol. 2004; 78:751-757. [PubMed: 14694107]

91. Buck CB, Thompson CD, Pang YY, Lowy DR, Schiller JT. Maturation of papillomavirus capsids. J Virol. 2005; 79:2839-2846. [PubMed: 15709003]

92. Bernard BA, Bailly C, Lenoir MC, Darmon M, Thierry F, Yaniv M. The human papillomavirus type 18 (HPV18) E2 gene product is a repressor of the HPV18 regulatory region in human keratinocytes. J Virol. 1989; 63:4317-4324. [PubMed: 2476572]

93. Thierry F, Yaniv M. The BPV1-E2 trans-acting protein can be either an activator or a repressor of the HPV18 regulatory region. EMBO J. 1987; 6:3391-3397. [PubMed: 2828029]

94. Jeon S, Lambert PF. Integration of human papillomavirus type 16 DNA into the human genome leads to increased stability of E6 and E7 mRNAs: implications for cervical carcinogenesis. Proc Natl Acad Sci U S A. 1995; 92:1654-1658. [PubMed: 7878034]

95. Akagi K, Li J, Broutian TR, Padilla-Nash H, Xiao W, Jiang B, Rocco JW, Teknos TN, Kumar B, Wangsa D, He D, Ried T, Symer DE, Gillison ML. Genome-wide analysis of HPV integration in human cancers reveals recurrent, focal genomic instability. Genome Res. 2014; 24:185-199. [PubMed: 24201445]

96. Vinokurova S, Wentzensen N, Kraus I, Klaes R, Driesch C, Melsheimer P, Kisseljov F, Durst M, Schneider A, von Knebel Doeberitz M. Type-dependent integration frequency of human papillomavirus genomes in cervical lesions. Cancer Res. 2008; 68:307-313. [PubMed: 18172324]

97. Pett M, Coleman N. Integration of high-risk human papillomavirus: a key event in cervical carcinogenesis? J Pathol. 2007; 212:356-367. [PubMed: 17573670]

98. Matsukura T, Koi S, Sugase M. Both episomal and integrated forms of human papillomavirus type 16 are involved in invasive cervical cancers. Virology. 1989; 172:63-72. [PubMed: 2549723] 
99. Johannsen E, Lambert PF. Epigenetics of human papillomaviruses. Virology. 2013; 445:205-212. [PubMed: 23953230]

100. Ojesina AI, Lichtenstein L, Freeman SS, Pedamallu CS, Imaz-Rosshandler I, Pugh TJ, Cherniack AD, Ambrogio L, Cibulskis K, Bertelsen B, Romero-Cordoba S, Trevino V, Vazquez-Santillan K, Guadarrama AS, Wright AA, Rosenberg MW, Duke F, Kaplan B, Wang R, Nickerson E, Walline HM, Lawrence MS, Stewart C, Carter SL, McKenna A, Rodriguez-Sanchez IP, Espinosa-Castilla M, Woie K, Bjorge L, Wik E, Halle MK, Hoivik EA, Krakstad C, Gabino NB, Gomez-Macias GS, Valdez-Chapa LD, Garza-Rodriguez ML, Maytorena G, Vazquez J, Rodea C, Cravioto A, Cortes ML, Greulich H, Crum CP, Neuberg DS, Hidalgo-Miranda A, Escareno CR, Akslen LA, Carey TE, Vintermyr OK, Gabriel SB, Barrera-Saldana HA, Melendez-Zajgla J, Getz G, Salvesen HB, Meyerson M. Landscape of genomic alterations in cervical carcinomas. Nature. 2014; 506:371-375. [PubMed: 24390348]

101. Isaacson Wechsler E, Wang Q, Roberts I, Pagliarulo E, Jackson D, Untersperger C, Coleman N, Griffin H, Doorbar J. Reconstruction of human papillomavirus type 16-mediated early-stage neoplasia implicates E6/E7 deregulation and the loss of contact inhibition in neoplastic progression. J Virol. 2012; 86:6358-6364. [PubMed: 22457518]

102. Munger K, Hayakawa H, Nguyen CL, Melquiot NV, Duensing A, Duensing S. Viral carcinogenesis and genomic instability. EXS. 2006:179-199. [PubMed: 16383019]

103. Tambouret RH. The evolution of the Papanicolaou smear. Clin Obstet Gynecol. 2013; 56:3-9. [PubMed: 23314726]

104. Stoler MH, Austin RM, Zhao C. Point-Counterpoint: Cervical Cancer Screening Should Be Done by Primary Human Papillomavirus Testing with Genotyping and Reflex Cytology for Women over the Age of 25 Years. J Clin Microbiol. 2015; 53:2798-2804. [PubMed: 25948606]

105. Huh WK, Ault KA, Chelmow D, Davey DD, Goulart RA, Garcia FA, Kinney WK, Massad LS, Mayeaux EJ, Saslow D, Schiffman M, Wentzensen N, Lawson HW, Einstein MH. Use of primary high-risk human papillomavirus testing for cervical cancer screening: interim clinical guidance. Obstet Gynecol. 2015; 125:330-337. [PubMed: 25569009]

106. Saslow D, Solomon D, Lawson HW, Killackey M, Kulasingam SL, Cain J, Garcia FA, Moriarty AT, Waxman AG, Wilbur DC, Wentzensen N, Downs LS Jr, Spitzer M, Moscicki AB, Franco EL, Stoler MH, Schiffman M, Castle PE, Myers ER, Committee A-A-ACCG. American Cancer Society, American Society for Colposcopy and Cervical Pathology, and American Society for Clinical Pathology screening guidelines for the prevention and early detection of cervical cancer. CA Cancer J Clin. 2012; 62:147-172. [PubMed: 22422631]

107. Wright T, Huang J, Baker E, Garfield S, Hertz D, Cox JT. The budget impact of cervical cancer screening using HPV primary screening. Am J Manag Care. 2016; 22:e95-e105. [PubMed: 26978241]

108. Hippelainen MI, Hippelainen M, Saarikoski S, Syrjanen K. Clinical course and prognostic factors of human papillomavirus infections in men. Sex Transm Dis. 1994; 21:272-279. [PubMed: 7817261]

109. Winer RL, Hughes JP, Feng Q, O’Reilly S, Kiviat NB, Holmes KK, Koutsky LA. Condom use and the risk of genital human papillomavirus infection in young women. N Engl J Med. 2006; 354:2645-2654. [PubMed: 16790697]

110. Marais D, Gawarecki D, Allan B, Ahmed K, Altini L, Cassim N, Gopolang F, Hoffman M, Ramjee G, Williamson AL. The effectiveness of Carraguard, a vaginal microbicide, in protecting women against high-risk human papillomavirus infection. Antivir Ther. 2011; 16:1219-1226. [PubMed: 22155903]

111. Naud PS, Roteli-Martins CM, De Carvalho NS, Teixeira JC, de Borba PC, Sanchez N, Zahaf T, Catteau G, Geeraerts B, Descamps D. Sustained efficacy, immunogenicity, and safety of the HPV-16/18 AS04-adjuvanted vaccine: final analysis of a long-term follow-up study up to 9.4 years post-vaccination. Hum Vaccin Immunother. 2014; 10:2147-2162. [PubMed: 25424918]

112. Nygard M, Saah A, Munk C, Tryggvadottir L, Enerly E, Hortlund M, Sigurdardottir LG, Vuocolo S, Kjaer SK, Dillner J. Evaluation of the Long-Term Anti-Human Papillomavirus 6 (HPV6), 11, 16, and 18 Immune Responses Generated by the Quadrivalent HPV Vaccine. Clin Vaccine Immunol. 2015; 22:943-948. [PubMed: 26084514] 
113. Joura EA, Giuliano AR, Iversen OE, Bouchard C, Mao C, Mehlsen J, Moreira ED Jr, Ngan Y, Petersen LK, Lazcano-Ponce E, Pitisuttithum P, Restrepo JA, Stuart G, Woelber L, Yang YC, Cuzick J, Garland SM, Huh W, Kjaer SK, Bautista OM, Chan IS, Chen J, Gesser R, Moeller E, Ritter M, Vuocolo S, Luxembourg A, Broad Spectrum HPVVS. A 9-valent HPV vaccine against infection and intraepithelial neoplasia in women. N Engl J Med. 2015; 372:711-723. [PubMed: 25693011]

114. Beavis AL, Levinson KL. Preventing Cervical Cancer in the United States: Barriers and Resolutions for HPV Vaccination. Front Oncol. 2016; 6:19. [PubMed: 26870696]

115. Markowitz LE, Dunne EF, Saraiya M, Chesson HW, Curtis CR, Gee J, Bocchini JA Jr, Unger ER. Centers for Disease, Prevention, Human papillomavirus vaccination: recommendations of the Advisory Committee on Immunization Practices (ACIP). MMWR Recomm Rep. 2014; 63:1-30.

116. Garland SM, Hernandez-Avila M, Wheeler CM, Perez G, Harper DM, Leodolter S, Tang GWK, Ferris DG, Steben M, Bryan J, Taddeo FJ, Railkar R, Esser MT, Sings HL, Nelson M, Boslego J, Sattler C, Barr E, Koutsky LA. I.I. Females United to Unilaterally Reduce Endo/Ectocervical Disease, Quadrivalent vaccine against human papillomavirus to prevent anogenital diseases. N Engl J Med. 2007; 356:1928-1943. [PubMed: 17494926]

117. Group FIS. Quadrivalent vaccine against human papillomavirus to prevent high-grade cervical lesions. N Engl J Med. 2007; 356:1915-1927. [PubMed: 17494925]

118. Paavonen J, Naud P, Salmeron J, Wheeler CM, Chow SN, Apter D, Kitchener H, Castellsague X, Teixeira JC, Skinner SR, Hedrick J, Jaisamrarn U, Limson G, Garland S, Szarewski A, Romanowski B, Aoki FY, Schwarz TF, Poppe WAJ, Bosch FX, Jenkins D, Hardt K, Zahaf T, Descamps D, Struyf F, Lehtinen M, Dubin G, Group HPS, Denham I, Garland S, Mindel A, O'Sullivan M, Skinner SR, Waddell R, de Carvalho N, Naud P, Teixeira JC, De Sutter P, Poppe WAJ, Tjalma W, Aoki FY, Diaz-Mitoma F, Dionne M, Ferguson L, Miller M, Papp K, Ramjattan B, Romanowski B, Somani R, Apter D, Astikainen S, Karppa T, Kekki M, Keranen H, Kudjoi N, Kuortti M, Kupari M, Kyha-Osterlund L, Isaksson R, Lehtinen M, Levanen H, Liljamo T, Loonberg K, Niemi L, Paavonen J, Palmroth J, Petaja T, Rekonen S, Romppanen U, SiitariMattila M, Tuomivaara L, Vilkki M, Belling KH, Gent T, Grubert T, Harlfinger W, Holst A, Hopker WD, Jensen-El Tobgui S, Merder G, Peters K, Schoenian S, Schulze K, Schwarz T, Wackernagel C, Boselli F, Mojana G, Salmeron J, Benitez G, Crisostomo C, Del RosarioRaymundo R, Germar MJ, Limson G, Raymundo J, Remollino MC, Villanueva G, Villanueva S, Zamora JD, Zamora L, Bajo J, Bayas J, Campins M, Castellsague X, Castro M, Centeno C, Cruzet F, Rodriguez L, Torne A, Vidart JA, Chow SN, Yu MH, Yuan CC, Huang SC, Ho HN, Chen RJ, Lin HH, Chu TY, Angsuwathana S, Jaisamrarn U, Wilawan K, Abdulhakim E, Cruickshank M, Kitchener H, Lewis D, Pavel I, Robinson J, Szarewski A, Ackerman R, Ault K, Bennett N, Caldwell M, Chambers C, Chatterjee A, Civitarese L, Demars L, De Santis T, Downs L, Ferris D, Fine P, Gall S, Harper D, Hedrick J, Herzig W, Hiraoka M, Huh W, Kamemoto L, Klein T, Koltun W, Kong A, Lalezari J, Lee P, Leeman L, Luber S, Martens M, Michelson J, Nebel W, Peterson C, Pitts K, Rosen J, Rosenfeld W, Scutella M, Seidman L, Sperling M, Sperling R, Stager M, Stapleton J, Swenson K, Thoming C, Twiggs L, Waldbaum A, Wheeler CM, Yardley M, Zbella E, Kiviat N, Klugman KP, Nieminen P, Bergeron C, Eisenstein E, Karron R, Marks R, Nolan T, Tay SK, Albers S, Bollaerts P, Camier A, Colau B, De Breyne A, Genevrois S, Issaka Z, Martens N, Peeters P, Smoes N, Spiessens B, Tavares F, Tonglet A, Vanden-Dunghen S, Vilain AS, Ward KR, Alt E, Iskaros B, Limaye A, Liu-Jarin X, Luff RD, McNeeley M, Provenzano C, Winkler B, Molijn A, Quint W, Struijk L, Van de Sandt M, Van Doorn LJ, Greenacre M, Baronikova S, Zahaf T, David MP, Declerck L, Dupin J, Maroye JL. Efficacy of human papillomavirus (HPV)-16/18 AS04-adjuvanted vaccine against cervical infection and precancer caused by oncogenic HPV types (PATRICIA): final analysis of a doubleblind, randomised study in young women. Lancet (London, England). 2009; 374:301-314.

119. Harper DM, Franco EL, Wheeler CM, Moscicki A-B, Romanowski B, Roteli-Martins CM, Jenkins D, Schuind A, Costa Clemens SA, Dubin G, group HPVVS. Sustained efficacy up to 4.5 years of a bivalent L1 virus-like particle vaccine against human papillomavirus types 16 and 18: follow-up from a randomised control trial. Lancet (London, England). 2006; 367:1247-1255.

120. Munoz N, Kjaer SK, Sigurdsson K, Iversen O-E, Hernandez-Avila M, Wheeler CM, Perez G, Brown DR, Koutsky LA, Tay EH, Garcia PJ, Ault KA, Garland SM, Leodolter S, Olsson S-E, Tang GWK, Ferris DG, Paavonen J, Steben M, Bosch FX, Dillner J, Huh WK, Joura EA, 
Kurman RJ, Majewski S, Myers ER, Villa LL, Taddeo FJ, Roberts C, Tadesse A, Bryan JT, Lupinacci LC, Giacoletti KED, Sings HL, James MK, Hesley TM, Barr E, Haupt RM. Impact of human papillomavirus (HPV)-6/11/16/18 vaccine on all HPV-associated genital diseases in young women. Journal of the National Cancer Institute. 2010; 102:325-339. [PubMed: 20139221]

121. Brown DR, Kjaer SK, Sigurdsson K, Iversen OE, Hernandez-Avila M, Wheeler CM, Perez G, Koutsky LA, Tay EH, Garcia P, Ault KA, Garland SM, Leodolter S, Olsson SE, Tang GW, Ferris DG, Paavonen J, Steben M, Bosch FX, Dillner J, Joura EA, Kurman RJ, Majewski S, Munoz N, Myers ER, Villa LL, Taddeo FJ, Roberts C, Tadesse A, Bryan J, Lupinacci LC, Giacoletti KE, Sings HL, James M, Hesley TM, Barr E. The impact of quadrivalent human papillomavirus (HPV; types 6, 11, 16, and 18) L1 virus-like particle vaccine on infection and disease due to oncogenic nonvaccine HPV types in generally HPV-naive women aged 16-26 years. J Infect Dis. 2009; 199:926-935. [PubMed: 19236279]

122. Wheeler CM, Castellsague X, Garland SM, Szarewski A, Paavonen J, Naud P, Salmeron J, Chow SN, Apter D, Kitchener H, Teixeira JC, Skinner SR, Jaisamrarn U, Limson G, Romanowski B, Aoki FY, Schwarz TF, Poppe WA, Bosch FX, Harper DM, Huh W, Hardt K, Zahaf T, Descamps D, Struyf F, Dubin G, Lehtinen M, Group HPS. Cross-protective efficacy of HPV-16/18 AS04adjuvanted vaccine against cervical infection and precancer caused by non-vaccine oncogenic HPV types: 4-year end-of-study analysis of the randomised, double-blind PATRICIA trial. Lancet Oncol. 2012; 13:100-110. [PubMed: 22075170]

123. Ali H, Donovan B, Wand H, Read TRH, Regan DG, Grulich AE, Fairley CK, Guy RJ. Genital warts in young Australians five years into national human papillomavirus vaccination programme: national surveillance data. BMJ (Clinical research ed ). 2013; 346:f2032.

124. Brotherton JML, Fridman M, May CL, Chappell G, Saville AM, Gertig DM. Early effect of the HPV vaccination programme on cervical abnormalities in Victoria, Australia: an ecological study. Lancet (London, England). 2011; 377:2085-2092.

125. Mesher D, Soldan K, Howell-Jones R, Panwar K, Manyenga P, Jit M, Beddows S, Gill ON. Reduction in HPV 16/18 prevalence in sexually active young women following the introduction of HPV immunisation in England. Vaccine. 2013; 32:26-32. [PubMed: 24211166]

126. Barr E, Tamms G. Quadrivalent human papillomavirus vaccine. Clin Infect Dis. 2007; 45:609607. [PubMed: 17682997]

127. Bonanni P, Bechini A, Donato R, Capei R, Sacco C, Levi M, Boccalini S. Human papilloma virus vaccination: impact and recommendations across the world. Ther Adv Vaccines. 2015; 3:3-12. [PubMed: 25553242]

128. Hildesheim A, Herrero R, Wacholder S, Rodriguez AC, Solomon D, Bratti MC, Schiller JT, Gonzalez P, Dubin G, Porras C, Jimenez SE, Lowy DR, Costa Rican HPVVTG. Effect of human papillomavirus 16/18 L1 viruslike particle vaccine among young women with preexisting infection: a randomized trial. JAMA. 2007; 298:743-753. [PubMed: 17699008]

129. Yang A, Jeang J, Cheng K, Cheng T, Yang B, Wu TC, Hung CF. Current state in the development of candidate therapeutic HPV vaccines. Expert Rev Vaccines. 2016:1-19.

130. Shope RE, Hurst EW. Infectious Papillomatosis of Rabbits : With a Note on the Histopathology. J Exp Med. 1933; 58:607-624. [PubMed: 19870219]

131. A.C. Society. Cancer Facts \& Figures 2016. Atlanta: American Cancer Society; 2016.

132. Chiao EY, Giordano TP, Palefsky JM, Tyring S, El Serag H. Screening HIV-infected individuals for anal cancer precursor lesions: a systematic review. Clin Infect Dis. 2006; 43:223-233. [PubMed: 16779751]

133. Bryan JT, Buckland B, Hammond J, Jansen KU. Prevention of cervical cancer: journey to develop the first human papillomavirus virus-like particle vaccine and the next generation vaccine. Curr Opin Chem Biol. 2016; 32:34-47. [PubMed: 26994695]

134. Markowitz LE, Hariri S, Lin C, Dunne EF, Steinau M, McQuillan G, Unger ER. Reduction in human papillomavirus (HPV) prevalence among young women following HPV vaccine introduction in the United States, National Health and Nutrition Examination Surveys, 20032010. J Infect Dis. 2013; 208:385-393. [PubMed: 23785124]

135. Cubie HA. Diseases associated with human papillomavirus infection. Virology. 2013; 445:21-34. [PubMed: 23932731] 
136. Said AK, Leao JC, Fedele S, Porter SR. Focal epithelial hyperplasia - an update. J Oral Pathol Med. 2013; 42:435-442. [PubMed: 23061874] 


\begin{tabular}{|c|c|c|}
\hline & ORF & HPV16 PROTEIN FUNCTION \\
\hline & E1 & $\begin{array}{l}\text { origin binding protein, ATPase-dependent helicase } \\
\text { involved in genome replication }\end{array}$ \\
\hline & E2 & $\begin{array}{l}\text { regulator of viral gene transcription, association with } \\
\text { E1 (origin binding), viral genome partitioning }\end{array}$ \\
\hline 790 & E4 & $\begin{array}{l}\text { expressed abundantly as } \mathrm{E} 1^{\wedge} \mathrm{E} 4 \text { fusion protein, } \\
\text { cytokeratin network destabilization, virus release and } \\
\text { transmission }\end{array}$ \\
\hline & E5 & $\begin{array}{l}\text { small transmembrane protein, interacts with EGF } \\
\text { receptor activating mitogenic pathways }\end{array}$ \\
\hline & E6 & $\begin{array}{l}\text { drives cell cycle allowing genome amplification in } \\
\text { upper epithelial layers, association with E6AP and } \\
\text { degradation of p53, PDZ-protein binding, hTert } \\
\text { activation }\end{array}$ \\
\hline \multirow{2}{*}{$\begin{array}{l}\text { EARLY REGION: proteins necessary for viral } \\
\text { replication }\end{array}$} & \multirow{2}{*}{ E7 } & \multirow{2}{*}{$\begin{array}{l}\text { drives cell cycle allowing genome amplification in } \\
\text { upper epithelial layers, association with and } \\
\text { degradation of pRB, mitotic mutator }\end{array}$} \\
\hline & & \\
\hline & \multirow{2}{*}{ E8 } & \multirow{2}{*}{$\begin{array}{l}\text { expressed as } E 8^{\wedge} E 2 \text { fusion protein, acts as a } \\
\text { repressor of transcription and replication during the } \\
\text { viral life cycle }\end{array}$} \\
\hline \multirow{2}{*}{ LATE REGION: viral capsid proteins } & & \\
\hline & L1 & $\begin{array}{l}\text { major capsid protein, assembles into pentameric } \\
\text { capsids forming the icosahedral virion (prophylactic } \\
\text { vaccines) }\end{array}$ \\
\hline $\begin{array}{l}\text { LONG CONTROLREGION: sequences } \\
\text { controlling viral replication \& transcription }\end{array}$ & L2 & $\begin{array}{l}\text { minor capsid protein, involved in viral DNA } \\
\text { encapsidation, facilitates viral entry and trafficking }\end{array}$ \\
\hline
\end{tabular}

Figure 1. HPV16 Genome Organization and Protein function

On the left, the HPV16 genomic map of 7906 base pairs is shown. Only the coding strand is included and transcription occurs in the clockwise direction. The early promoter $\left(\mathrm{P}_{97}\right)$ is indicated by an arrow at the approximate position of the RNA initiation site in the long control region LCR. The late promoter $\left(\mathrm{P}_{670}\right)$ is also indicated by an arrow at its initiation site in the E7 ORF. The early region is depicted in blue and contains proteins necessary for viral replication including E1, E2, E3, E4, E5, E6 and E7. The late region is shown in purple and contains the viral capsid proteins L1 and L2. The LCR is shown in green and contains sequences controlling viral replication \& transcription. On the right, a table of the HPV16 ORFs and a brief description of their corresponding viral functions is shown. More details can be found in section 1.3 of the text. 


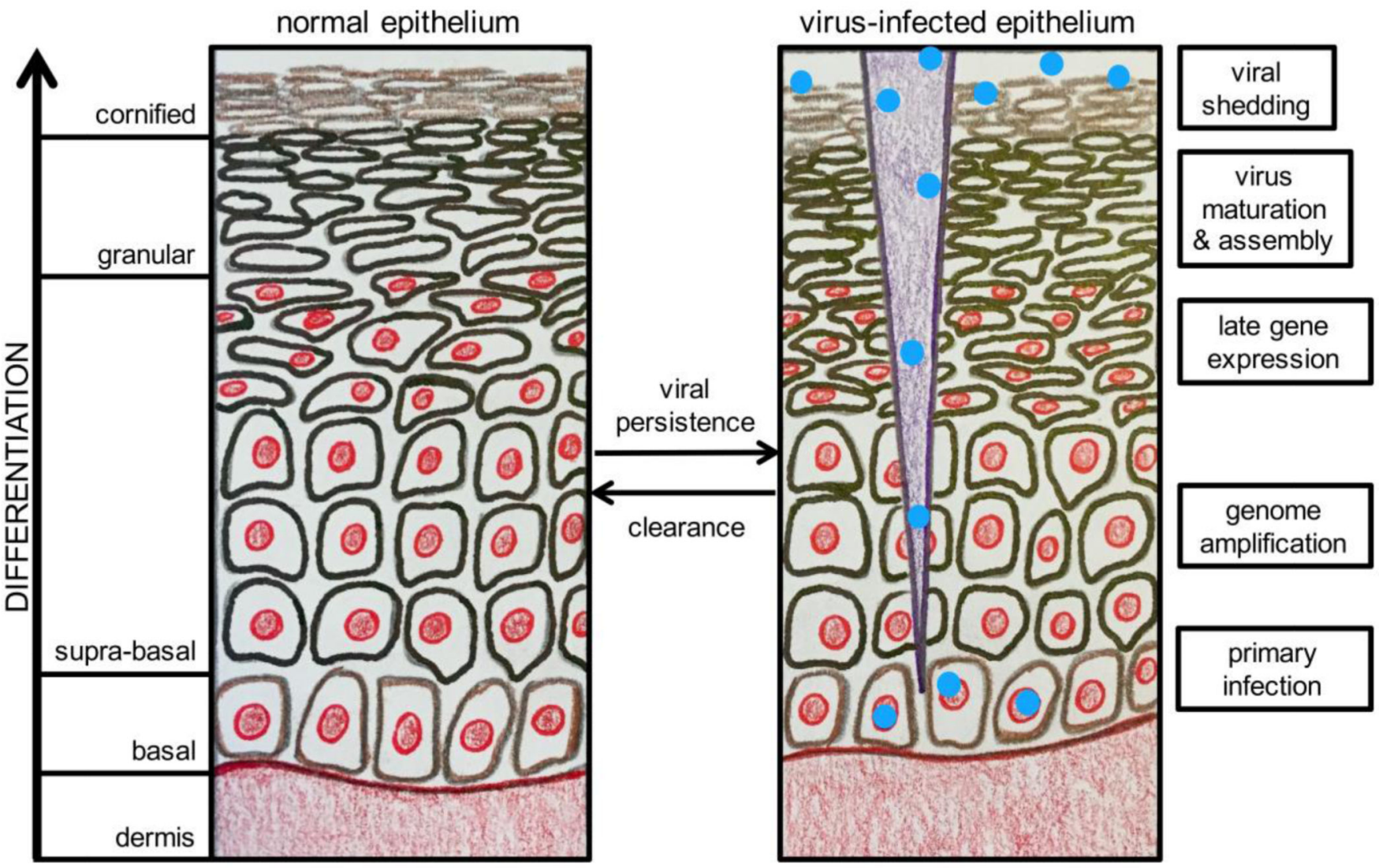

Figure 2. The HPV Lifecycle in Differentiating Squamous Epithelium

An illustration of normal differentiating squamous epithelium is shown on the left with the layers of the differentiating epithelium noted. On the right, a brief description of the HPV life cycle stage occurring in the corresponding epithelial layer is shown. Greater detail on HPV productive infection and the viral life cycle is included in section 1.5. This figure was illustrated by M. E. Harden and adapted from a figure by C. L. Nguyen. 


\section{Table 1}

Main HPV genotypes and their associated diseases.

\begin{tabular}{|c|c|c|c|c|}
\hline Genus & Species & Representative HPV types & Tropism & Associated Diseases \\
\hline \multirow{7}{*}{ Alpha-PV } & a1 & 32 & mucosal & Heck's disease \\
\hline & a2 & $3,10,28$ & cutaneous & flat warts \\
\hline & a4 & $2,27,57$ & cutaneous & common warts \\
\hline & a7 & $18,39,45,59,68$ & mucosal & intraepithelial neoplasia, invasive carcinoma \\
\hline & a9 & $16,31,33,35,52,58$ & mucosal & intraepithelial neoplasia, invasive carcinoma \\
\hline & a10 & 6,11 & mucosal & condylomata acuminate \\
\hline & & 13 & & Heck's disease \\
\hline \multirow{3}{*}{ Beta-PV } & $\beta 1 \mathrm{c}$ & $\begin{array}{l}5,8,12,14,19,20,21,24, \\
25,36,47\end{array}$ & cutaneous & $\begin{array}{l}\text { Epidermodysplasia } \\
\text { verruciformis }\end{array}$ \\
\hline & $\beta 2$ & $9,15,17,22,23,37,38$ & cutaneous & $\begin{array}{l}\text { Epidermodysplasia } \\
\text { verruciformis }\end{array}$ \\
\hline & $\beta 3$ & 49 & cutaneous & $\begin{array}{l}\text { Epidermodysplasia } \\
\text { verruciformis }\end{array}$ \\
\hline \multirow{2}{*}{ Gamma-PV } & $\gamma 1$ & 4,65 & cutaneous & Warts \\
\hline & $\gamma 4$ & 60 & cutaneous & Warts \\
\hline \multirow{2}{*}{ Mu-PV } & $\mu 1$ & 1 & cutaneous & plantar warts \\
\hline & $\mu 2$ & 63 & cutaneous & Warts \\
\hline Nu-PV & $\mathbf{v}$ & 41 & cutaneous & Warts \\
\hline
\end{tabular}

This table summarizes information on the main HPV genotypes, their tropism and associated diseases. Information in this table was gathered from several sources including pave.niaid.nih.gov [6, 7, 135]. Heck's disease, also known as focal epithelial hyperplasia (FEH), is a rare, benign mucosal proliferation that is strongly associated with HPV infection [136]. Other details on HPV classification can be found in the text in section 1.2. 